Dr Vasilije Mišković, pukovnik, dipl. inž.

Dr Petar Stanojević, major, dipl. inž. Vojnotehnicka akademija VJ. Beograd
KRITERIJUMI ZA OCENU VARIJANTNIH REŠENJA ORGANIZACIJE LOGISTIČKE PODRŠKE - POZADINSKOG OBEZBEĐENJA

UDC: $355.41 .001 .26: 65.01$

Rezime:

U radu je prikazan način izdvajanja, definisanja, formalizacije i struktuiranja kriterijuma $z a$ ocenu složenih organizaciono-tehnoloskih sistema. Izbor, definisanje, formalizaciju $i$ struktuiranje kriterijuma nije moguce izvrsiti bez poznavanja samog organizaciono-tehnološkog sistema, problema, predmeta $i$ cilja ocenjivanja, izbora modela ocenjivanja, metode za ocenu i rangiranje. $U$ clanku su na primeru prikazani, u opstem obliku, moguci kriterijumi za ocenu $i$ rangiranje varijanti organizacije logistickih - pozadinskih sistema. Izdvajanje, struktuiranje i prikaz kriterijuma za ocenu i rangiranje organizacije logistickih - pozadinskih sistema, uradeno je radi sagledavanja sadržaja razmatranja, a manje zbog konačnih kriterijuma.

Ključne reči: kriterijum, ocena, logisticki sistem, višekriterijumska optimizacija.

\title{
CRITERIA FOR THE EVALUATION OF LOGISTIC SUPPORT ORGA- NIZATIONAL VARIANTS
}

\section{Summary:}

The paper presents the way of choosing, defining, formalizing and structuring criteria for the evaluation of complex organizational and technological systems. Choice, definition, formalization and structuring of criteria are impossible to be realized without knowing the very organizational-technological system, problems, evaluation subject and objective, choice of an evaluation model, evaluation method and ranking. The paper gives a general form of possible criteria for the evaluation and ranking of organizational variants of logistic systems. Choice, structuring and presenting evaluating criteria as well as ranking of logistic systems organizations has been performed more for the sake of their review and less for the sake of giving final criteria.

Key words: criterion, evaluation, logistic system, multicriteria optimization.

\section{Uvod}

Problemi i ciljevi ocenjivanja, kao i modeli za ocenu složenih organizaciono-tehnoloških sistema (OTS), u koji spada logistički - pozadinski sistem, mogu biti različiti. Ono što je u ocenjivanju invarijantno jeste neophodnost postojanja kri- terijuma za ocenu. Kriterijumi nužno moraju da postoje pri ocenjivanju OTS-a, što ne znači da u svakom modelu ocenjivanja oni moraju biti strogo formalizovani. Da li ce i kako kriterijumi biti formalizovani zavisi od primenjenog modela ocenjivanja, a njegov izbor zavisi od karakteristika OTS-a, od cilja ili ciljeva 
ocenjivanja, problema koji se tom prilikom javljaju, itd.

Ako se u modelima ocenjivanja ne zahteva strogo definisanje, formalizovanje i struktuiranje kriterijuma, to ne znači da oni ne postoje. Na primer, u modelu ocene gde se varijante OTS-a rangiraju na osnovu ekspertske ocene ranga, kriterijumi se formalno ne pojavljuju. Međutim, da bi svaki od eksperata mogao da uspostavi sopstveni rang varijanti, uspostavlja i sopstvene kriterijume za ocenu i rangiranje varijanti. U ovom slučaju, kriterijumi nisu identični kod svih eksperata, kao ni relativna važnost tih kriterijuma, ali je bitno da oni postoje.

Cilj ovog rada jeste da se izdvoje, struktuiraju i prikažu, u opštem obliku, mogući kriterijumi za ocenu i rangiranje varijanti organizacije logističkih - pozadinskih sistema. Dakle, sugerǐ̌e se šta bi pri ocenjivanju trebalo da bude predmet ocene, a ne daju se konačni kriterijumi. Uostalom, definisanje, formalizaciju i struktuiranje kriterijuma nije moguće izvršiti bez prethodno potpunog poznavanja problema, predmeta i cilja ocenjivanja, kao i izbora modela ocenjivanja. ${ }^{1}$

Kada je u pitanju materijalna i zdravstvena podrška vojske, u različitim armijama u svetu, po najgrubljoj klasifikaciji, pojavljuju se logistički sistemi podř̌ke i pozadinski sistemi podrške. Po kategorijalno-pojmovnom određenju pojam logističke podrške i pojam pozadinske podrske kod nas nije jasno razgraničen. Osnovni uzroci tome su da su i logisticki i pozadinski sistem samo dva organizaciona oblika jednog istog sistema koji imaju istu namenu $\mathrm{i}$ cilj postojanja, $\mathrm{i}$ da u svetu ne postoje realni sistemi sa „Xistim“ oblicima organizovanja. Radi toga ovog rada. će u ovom radu pod pojmom logistička podrška biti podrazumevan sistem čija organizaciona struktura teži funkcionalnoj, a pod pojmom pozadinska podrška sistem čija organizaciona struktura teži departmanskoj (linijsko-štabnoj) organizacionoj strukturi. S obzirom na to da je namena i cilj postojanja ovakvih sistema ista, bez obzira na organizacione oblike, to su i kriterijumi za njihovu ocenu isti ili veoma slični. U ovom radu biće korišcen termin logistički - pozadinski sistem vojske (LPSV).

\section{Osnovne karakteristike logističkih - pozadinskih sistema vojske}

Posmatrano u užem smislu LPSV predstavlja podsistem vojske koji ima za cilj da opsluži materijalne i zdravstvene potrebe vojnog sistema u celini. U šrem smislu, on je specifican uslužno-proizvodni sistem sa mnogo karakterističnih dimenzija, namenjen za postizanje velikog broja sadržinski različitih potciljeva za čije se potrebe mora formirati složena organizacija, i koristiti široka paleta raznorodnih resursa. $\mathrm{U}$ tom smislu može se posmatrati kao složen OTS.

Do nedavno se smatralo da se osnovna specifičnost ovog sistema ogleda u tome da on može funkcionisati u dva znatno različita stanja - ratnom i mirnodopskom. Zakonitosti i zahtevi funkcionisanja u jednom i drugom stanju evidentno se razlikuju. Osnovni cilj, odnosno svoju svrsishodnost, ovaj sistem nedvosmisleno postiže ako uspe da obezbedi nesmetano funkcionisanje $u$ ratu. Zbog toga je rat referentno stanje sistema. Prema tome, mirnodopsko stanje može biti samo izvedeno stanje, koje se mora karakterisati maksimalnom racionalizacijom i ekonomičnošću funkcionisanja. Da- 
nas se nameće potreba za razmatranjem i trećeg značajnog stanja - kriznog stanja, koje se karakteriše raznolikošcu pojavnih oblika i intenziteta ispoljavanja. Potrebu za njegovim razmatranjem inicirala su iskustva razlicitih zemalja, iskustva iz događaja na tlu nekadašnje Jugoslavije, permanentnih kriznih žarišta na nekim delovima teritorije SRJ, ali i doktrinarnih opredeljenja nekih armija relevantnih zemalja, u kojima se već duže vreme ovakvo stanje razmatra. Pored navedenog u „krizne situacije" se mogu ubrojati i funkcionisanje vojske u slučaju elementarnih katastrofa. Proizilazi da su referentna stanja u kojima funkcioniše LPSV rat, krizno stanje i mir.

Zahtevi za bilo kojim vidom materijalnog ili zdravstvenog obezbeđenja po svojoj prirodi toliko se razlikuju da se ovaj sistem po tipu tehnologije može svrstati u pojedinačni, a tek u nekim slučajevima u maloserijski i srednjeserijski tip.

\section{Izbor karakterističnih kriterijuma za rangiranje $i$ ocenu varijanti organizovanja LPSV}

Polazna osnova za određivanje kriterijuma koji će biti uvršteni u model za ocenjivanje varijantnih rešenja organizovanja LPSV $i$ njegovih podsistema - funkcija zasniva se na obuhvatu kriterijuma i principa koji se koriste za ocenu valjanosti LPSV, kao i na kriterijumima koje za kvalitet materijalnih sredstava $i$ uslužne delatnosti (LPSV predstavlja upravo takav sistem, kao i svi drugi logistički sistemi) propisuju standardni ISO-JUS-SNO 9000 i $10000 .^{2}$ Uporedni pregled

${ }^{2}$ Kriterijumi definisani serijom standarda ISO-JUS 9000 i 10000 navedeni su samo radi uporedenja, ovih kriterijuma i principa koji se koriste kao kriterijumi, prikazan je u tabeli 1 .

$\mathrm{U}$ tabeli su namerno navedeni ,kriterijumi - principi pozadinskog obezbeđenja", jer se smatralo da se svaki od principa organizovanja pozadinskog obezbeđenja može u određenoj situaciji proglasiti i za kriterijum uspešnosti konkretnog organizacionog rešenja. ${ }^{3}$

Pregled kriterijuma u tabeli struktuiran je tako da su paralelno (po redovima) dati istovetni ili sadržajno istovetni kriterijumi. Sadržaj i značenje ovih kriterijuma prikazan je u literaturi Komparativna analiza, ISO 9000 , N. Vujanović, tako da se neće opširnije obrazlagati. Očigledna je izuzetna sličnost kriterijuma koji se primenjuju u sva tri slučaja.

Navedene čnjenice govore o sveobuhvatnosti, pogodnosti i opštoj prihvaćenosti navedenih kriterijuma za ocenu valjanosti - svrsishodnosti sistema koji se bave podrškom sistema „osnovne" delatnosti, u ovom slučaju onog dela vojnog sistema kome je osnovni zadatak izvođenje udara, odnosno pokreta, vatre i manevra. To i jeste osnovni opredeljujući faktor za izbor konkretnih kriterijuma preko kojih bi se merila valjanost varijantnih rešenja u organizovanju LPSV. Međutim, postoje i izvesne specifičnosti na koje posebno treba obratiti pažnju. To se odnosi na kriterijume efektivnosti (koji opisuje postizanje osnovnog cilja postojanja nekog sistema - npr. za funkciju održavanja to je operativna gotovost raspoloživost tehnickih sredstava) i efikasnosti (koji opisuje koliko je "napora“ potrebno, odnosno kojom se brzinom i kolikim angažovanjem - utroł̌kom resursa postiže cilj posmatranog sistema).

${ }^{3}$ Jasno i potpuno razgraniđenje među nacelima, principima, kriterijumima i ograničnjima moguce je u slučaju formulisanja problema i određenja odnosnog predmeta. 
Uporedni pregled kriterijuma i principa logističke podrške, pozadinskog obezbedenja i ISO 9000 i 10000

\begin{tabular}{|c|c|c|}
\hline $\begin{array}{l}\text { Kriterijumi valjanosti } \\
\text { sistema logisticke } \\
\text { podrśke }\end{array}$ & $\begin{array}{c}\text { Kriterijumi - principi } \\
\text { pozadinskog obezbeđenja }\end{array}$ & $\begin{array}{l}\text { Kriterijumi kvaliteta teh- } \\
\text { nickih sredstava i usluga } \\
\text { po ISO } 9000 \text { i } 10000\end{array}$ \\
\hline $\begin{array}{l}\text { Efektivnost } \\
\text { Efikasnost } \\
\text { Integracija } \\
\text { Autonomnost } \\
\text { Kontinuitet } \\
\text { Improvizacija - elastiČnost } \\
\text { Teritorijalnost } \\
\text { Ekonomičnost } \\
\text { Realnost } \\
\text { Fleksibilnost } \\
\text { Predviđanje } \\
\text { Pokretljivost } \\
\text { Sigurnost } \\
\text { Jednostavnost }\end{array}$ & $\begin{array}{l}\text { Efektivnost } \\
\text { Efikasnost } \\
\text { Integralnost } \\
\text { Autonomnost } \\
\text { Neprekidnost } \\
\text { Univerzalnost } \\
\text { Teritorijalna organizacija } \\
\text { Ekonomičnost, racionalnost } \\
\text { Brz prelazak na rat } \\
\text { Elastičnost, adaptabilnost } \\
\\
\\
\\
\text { Jedinstvo } \\
\text { Pravovremenost } \\
\text { Nepodeljenost odgovornosti } \\
\text { Jedinstvo informacionog sistema } \\
\text { Priprema kapaciteta i teritorije za rat u miru } \\
\text { Utvrđenost nadležnosti i odgovornosti }\end{array}$ & $\begin{array}{l}\text { Opiplijivost } \\
\text { Pouzdanost } \\
\text { Sigurnost } \\
\text { Kompetentnost } \\
\text { Ljubaznost } \\
\text { Verodostojnost } \\
\text { Pristup }\end{array}$ \\
\hline
\end{tabular}

Kao kriterijume za ocenu kvaliteta sistema logističke podrške, pojedini strani (vojni) autori eksplicitno navode posebne kriterijume efektivnosti i efikasnosti, a neki ih ne navode iako ih u praksi evidentno koriste. U nekim armijama ovi se kriterijumi određuju kao osnovni - vršni za ocenu valjanosti sistema LPSV (komparativna analiza). To, kao i iskustva iz dosadašnje teorije i prakse upravljanja posmatranim sistemom, navode na zaključak da se pored navedenih kriterijuma za ocenu LPSV moraju uvesti i neki dodatni koji bi bliže odredili valjanost pojedinih varijantnih rešenja organizovanja, ali i valjanost organizacije pojedinih funkcija LPSV.

Takođe, važno je uočiti da u ovom slučaju može da se radi i o projektovanju novog i ocenjivanju i reprojektovanju postojećeg LPSV. Da bi bili obuhvaćeni svi navedeni slučajevi ne može se direktno iz literature preuzeti jedan deo navedenih kriterijuma, jer oni, u stvari, čine principe - načela na kojima se grade modeli, odnosno moraju se isključivo zadati unapred, pa su zbog toga invarijantni i nema potrebe za njihovim ocenjivanjem - određivanjem. Načelno, u takve kriterijume - principe spadaju (što ne važi za svaki konkretan slučaj ocenjivanja):

- integracija - u potpunosti zavisi od generisanog varijantnog rešenja organizovanja, pa nije relevantan kao kriterijum;

- autonomnost - predstavlja princip

na kojem se gradi model i mora se zadati unapred, pa kao kriterijum nije relevan$\tan$; 
- kontinuitet - predstavlja princip na kojem se gradi model, jer bez njega nema smislenih varijantnih rešenja, pa kao kriterijum nije relevantan;

- teritorijalnost - u potpunosti zavisi od generisanog varijantnog rešenja organizovanja, pa nije relevantan kao kriterijum;

- realnost - varijantna rešenja koja ne omogućavaju prelazak mirnodopske u ratnu armiju nema smisla razmatrati, jer se to mora podrazumevati kao uslov bez kojeg nije moguće projektovati ratnu armiju, pa nije relevantan kao kriterijum. Suštinski je već uključen kroz, u daljem tekstu, kriterijum jednostavnosti;

- predviđanje - obezbeđuje se kroz uspešno generisana varijantna rešenja organizovanja, a suštinski je obuhvaćeno preko kriterijuma elastičnosti i fleksibilnosti, pa nije relevantan kao kriterijum;

- sigurnost - suštinski je uključen u kriterijum efektivnost, pa nije relevantan kao kriterijum;

- jedinstvo - to je princip koji je važio u JNA i opisivao stepen sličnosti i povezanosti jedinica JNA i TO po pitanju pozadinskog obezbeđenja. U današnje vreme može se tumačiti kao postulat o jedinstvenom pozadinskom obezbeđenju ratne i mirnodopske armije, što je princip bez kojeg je besmisleno graditi bilo koje varijantno rešenje organizovanja u ovom slučaju;

- pravovremenost - predstavlja princip organizovanja, a suštinski je uključen u kriterijum efektivnost, pa nije relevantan kao kriterijum;

- nepodeljenost odgovornosti - u potpunosti zavisi od generisanog varijantnog rešenja organizovanja, predstavlja suštinski princip izgradnje organizacionih sistema, pa nije relevantan kao kriterijum;
- jedinstvo informacionog sistema u potpunosti zavisi od generisanog varijantnog rešenja organizovanja, pa nije relevantan kao kriterijum;

- priprema kapaciteta i teritorije za rat u miru - u potpunosti zavisi od generisanog varijantnog rešenja organizovanja, pa nije relevantan kao kriterijum;

- utvrđenost nadležnosti i odgovornosti - predstavlja temeljan princip organizacije rada, pa nije relevantan kao kriterijum. Takođe, više je vezan za sistem PoOb, pa nije invarijantan;

- kompetentnost, ljubaznost i verodostojnost - predstavljaju početne premise projektovanja realnih uslužnih sistema, pa nisu relevantni kao kriterijumi.

Dakle, koncipiranje modela uspešnosti mora se zasnivati na obuhvatu celine funkcionisanja LPSV $\mathrm{i}$ njegovih delova, kao entiteta koji imaju odlike poslovnog - uslužnog sistema. Da bi se obezbedila invarijantnost, ukupna uspešnost LPSV - E(t) bi se mogla, uslovno, tumačiti kao funkcija efektivnosti (Ef), organizacione efikasnosti (Eo), ekonomske komponente (Ee) i efektivnosti ispunjenja karakterističnih zahteva vojnog sistema (Ev):

\section{$E(t)=f(E f, E o, E e, E v)$}

Svaka od ovih komponenti istovremeno određuje uspešnost LPSV u obliku serijske veze. Fizički deo projektovanog sistema definiše se tehnološkim projektom, veze određuju organizacionom upravljačkom strukturom, a procesi ostvaruju upravljanjem. $\mathrm{Na}$ osnovama rašclanjivanja i analize filozofije koncipiranja modela $i$ iznetih kriterijuma, kao opšti kriterijumi za ocenu sistema LPSV mogu se odrediti: efektivnost, efikasnost, 
elastičnost, ${ }^{4}$ fleksibilnost, troškovi, jednostavnost, pokretljivost.

Radi bližeg određenja, kriterijumi efektivnosti i ekonomičnosti govore sami za sebe, kriterijumi efikasnosti, elastičnosti i fleksibilnosti opisuju organizovanost (kvalitet projektovane organizacije), dok kriterijumi jednostavnosti i pokretljivosti predstavljaju kriterijume specifične za ostvarenje svrhe vojnog sistema kao celine.

Zbog svoje kompleksnosti na najvišem nivou razmatranja, odnosno kada se bude posmatrao LPSV kao celina, ne preostaje ništa drugo već da se vrednosti ovih kriterijuma ekspertski ocenjuju na osnovu pokazatelja varijantnih rešenja pojedinih funkcija. Međutim, na nižem nivou - nivou pojedinih funkcija LPSV, ovi kriterijumi se moraju razraditi i po mogućnosti svoje vrednosti dobiti putem korišćenja adekvatnih simulacionih ili analitičkih modela za proračun.

\section{Opis kriterijuma}

EFEKTIVNOST - služi za ocenu u kojoj meri je LPSV u stanju da u toku funkcionisanja na predviđeni način i sa predviđenim intenzitetom zahteva, iste zadovolji. Po ovom kriterijumu sistem je potrebno oceniti u ratu, miru i kriznim situacijama. Kriterijumske vrednosti dobijaju se modelovanjem.

EFIKASNOST - služi za ocenu koliko sistem ono što može da realizuje realizuje brzo i koliko je opterećenje pojedinih delova u sistemu. Kriterijum je opisan sa više potkriterijuma. Sve kriterijumske vrednosti se dobijaju modelovanjem.

ELASTIČNOST - služi za ocenu u kojoj meri je sistem u stanju da na sebe

${ }^{4}$ Elastićnost i feksibilnost se u literaturi tumace nu razlicite načine, $\mathrm{U}$ ovom radu ih treba shvatiti onako kako su ovde definisani. prihvati udare, odnosno u kojoj meri može da zadovolji potrebe pri ekstremno velikim zahtevima i pri gubitku dela svojih resursa. Ovaj kriterijum opisuje se sa više potkriterijuma, koji takođe imaju svoje potkriterijume. Kriterijumske vrednosti za ovaj kriterijum izražavaju se na isti način kao i kod kriterijuma efektivnosti, a dobijaju se modelovanjem.

FLEKSIBILNOST - služi za ocenu u kojoj meri je sistem u stanju da se u toku funkcionisanja na predviđeni način prilagodi konkretnoj situaciji, u kojoj meri je sposoban da se prilagodi kriznim situacijama, i u kojoj meri je sposoban da se prilagodi (reorganizuje) za situacije koje mogu nastati. Ovaj pokazatelj organizovanosti sistema zavisi i od karakteristika kadra koji radi u sistemu, kao sto su npr. obučenost za vršenje različitih dužnosti, motivisanost, inventivnost, itd. Sa fleksibilnošću ima veze i broj jedinica ili resursa (organizovanih u pogodne modularne celine) koji upravljanju stoje na raspolaganju u bilo kojoj situaciji. Zbog toga je veoma teško kvantifikovati sve aspekte ovog kriterijuma, pa je opisan sa više potkriterijuma, a kriterijumske vrednosti se dobijaju ekspertskom ocenom i modelovanjem.

TROŠKOVI - pokazuju koliki resursi moraju biti angažovani da bi sistem imao karakteristike koje su predstavljene kriterijumskim vrednostima. Ovaj kriterijum opisan je sa više potkriterijuma, koji imaju svoje potkriterijume. Kriterijumske vrednosti za sve potkriterijume su brojevi u apsolutnom iznosu ili se izražavaju u operativno-proračunskim jedinicama. Kriterijumske vrednosti određuju se modelovanjem. Važno je da se isti troškovi zaračunavaju kod svih varijanti, kako bi se moglo izvršiti upoređenje. Varijante koje zahtevaju znatno više tehnoloskih elemenata (TE) i/ili zaposlenih, oči- 
gledno su skuplje, jer postoji značajna korelacija između nepromenljivih troskova i ukupnih troškova funkcionisanja sistema. Preliminarno rangiranje varijanti može se izvršiti i samo prema nekim veličinama, npr. potrebnom broju zaposlenih, broju TE, visini zaliha, itd., jer oni sigurno čine većinu troškova (A. A. Anders i dr., 1982). Proizilazi da se rangiranje varijanti po ovom kriterijumu može pouzdano izvršiti upoređivanjem nepromenljivih troškova, koji svoj iskaz imaju u broju potrebnih najznačajnijih tehnoloških elemenata (TE), visini materijalnih rezervi i broju potrebnog ljudstva.

JEDNOSTAVNOST - služi za ocenu mogućnosti sistema da na lak način pređe iz jednog relevantnog stanja u drugo, kao i to da se u sistemu ostvari tok materijala $i$ informacija najkraćim putem bez nepotrebnog zadržavanja, suvišnih manipulacija materijalnih sredstava i nepotrebnih obrada informacija. Ovaj kriterijum opisan je sa više potkriterijuma, od kojih neki takođe imaju svoje potkriterijume kroz koje su izražene kriterijumske vrednosti kriterijuma. Vrednosti ovih potkriterijuma dobijaju se modelovanjem i ekspertskom ocenom.

POKRETLJIVOST - služi za ocenu u kojoj meri je sistem u stanju da dislocira svoje resurse iz stacionarnih objekata, i vrši potrebne manevre resursima. Vrednosti potkriterijuma dobijaju se modelovanjem.

\section{Primeri struktuiranja kriterijuma po osnovnim funkcijama LPSV}

Problem određivanja kriterijumskih vrednosti, odnosno težnja da se kriterijumske vrednosti izražavaju fizički merljivim veličinama, nameću potrebu postojanja izuzetno velikog broja kriterijuma.
Zbog toga se kriterijumi najčešce hijerarhijski struktuiraju, kao što je urađeno i u ovom primeru.

$\mathrm{U}$ ovom radu dati su kriterijumi za ocenu i rangiranje varijanti LPSV za funkciju održavanja i funkciju snabdevanja i transporta (tabele 2 i 3 ).

$\mathrm{Na}$ osnovu iznetog, neki od izabranih kriterijuma za ocenu sistema održavanja, kao potceline LPSV, imaju određene karakteristike.

\section{$\mathbf{K}_{1}^{0}$ - EFEKTIVNOST}

Izrazi za izračunavanje operativne gotovosti poznati su u teoriji, a zasnivaju se na odnosu vremena kada se grupa ili jedno TS moglo angažovati, i vremena kada se to angažovanje zahtevalo. Kod vojnih sistema gde postoje gubici TS, bilo povratni ili nepovratni, i gde je cilj SOd-a još i spasavanje TS izvlačenjem i evakuacijom raspoloživost se, uslovno, može odrediti kao odnos srednje vrednosti broja ispravnih sredstava NVO prema ukupnom broju sredstava NVO u nekom periodu.

Gubici sredstava NVO zbog nepravovremenog izvř̌enja radnji održavanja u ratu određuju se kao i broj sredstava koja je zarobio neprijatelj u toku izvršenja ratnih dejstava.

\section{$\mathrm{K}_{2}^{0}$ - EFIKASNOST}

Srednje vreme zastoja izražava se u danima.

Iskorišćenje se izražava u procentima (vreme korišćenja u odnosu prema potrebnom vremenu korišćenja).

Raspon opterećenja komandnih nivoa po broju informacija koje se moraju obraditi izražava se po čoveku u jedinici vremena. 
Kriterijumi za ocenu sistema održavanja

\begin{tabular}{|c|c|c|c|}
\hline $\begin{array}{l}\text { Kriterijum } \\
0 . \text { nivoa }\end{array}$ & $\begin{array}{l}\text { Kriterijum } \\
\text { 1. nivoa }\end{array}$ & $\begin{array}{l}\text { Kriterijum } \\
\text { 2. nivoa }\end{array}$ & $\begin{array}{c}\text { Način određivanja } \\
\text { kriterijumskih vrednosti }\end{array}$ \\
\hline \multirow{4}{*}{$\begin{array}{l}\text { EFEK- } \\
\text { TIVNOST }\end{array}$} & $\begin{array}{l}\begin{array}{l}\text { Operativna gotovost sredstava NVO u } \\
\text { miru }\end{array} \\
\end{array}$ & \multirow{4}{*}{$\begin{array}{l}\text { Po vrstama sred- } \\
\text { stava }\end{array}$} & \multirow{4}{*}{$\begin{array}{l}\text { Raspoloživost se može } \\
\text { odrediti kao odnos sred- } \\
\text { nje vrednosti broja is- } \\
\text { pravnih sredstava NVO } \\
\text { prema ukupnom broju } \\
\text { sredstava NVO u nekom } \\
\text { periodu. } \\
\text { Gubici sredstava NVO } \\
\text { zbog nepravovremenog } \\
\text { izvrsenja radnji održava- } \\
\text { nja u ratu određuju se } \\
\text { kao broj sredstava koja } \\
\text { su zarobljena. }\end{array}$} \\
\hline & $\begin{array}{l}\text { Operativna gotovost sredstava NVO u } \\
\text { kriznoj situaciji }\end{array}$ & & \\
\hline & $\begin{array}{l}\text { Operativna gotovost sredstava NVO u } \\
\text { ratu }\end{array}$ & & \\
\hline & $\begin{array}{l}\text { Gubici sredstava NVO zbog nepravo- } \\
\text { vremenog izvrsenja radnji održavanja } \\
\text { u ratu }\end{array}$ & & \\
\hline \multirow{11}{*}{$\begin{array}{l}\text { EFIKAS- } \\
\text { NOST }\end{array}$} & $\begin{array}{l}\text { Srednje vreme zastoja zbog održavanja } \\
\text { kategorije sredstava NVO u miru }\end{array}$ & \multirow{6}{*}{$\begin{array}{l}\text { Po vrstama sred- } \\
\text { stava }\end{array}$} & \multirow{11}{*}{$\begin{array}{l}\text { Srednje vreme zastoja iz- } \\
\text { ražava se u danima. } \\
\text { Iskorisćenje se izražava u } \\
\text { procentima (vreme koriš- } \\
\text { ćenja u odnosu na po- } \\
\text { trebno vreme koriśce- } \\
\text { nja). } \\
\text { Raspon opterećenja ko- } \\
\text { mandnih nivoa po broju } \\
\text { informacija koje se mo- } \\
\text { raju obraditi izražava se } \\
\text { po coveku u jedinici vre- } \\
\text { mena. }\end{array}$} \\
\hline & $\begin{array}{l}\text { Srednje vreme zastoja zbog održavanja } \\
\text { kategorije sredstava NVO u kriznoj } \\
\text { situaciji }\end{array}$ & & \\
\hline & $\begin{array}{l}\text { Srednje vreme zastoja zbog održavanja } \\
\text { kategorije sredstava NVO u ratu }\end{array}$ & & \\
\hline & $\begin{array}{l}\text { Procenat izvršenih preventivnih radova } \\
\text { održavanja (od predviđenih) na katego- } \\
\text { rijama sredstava NVO u miru }\end{array}$ & & \\
\hline & $\begin{array}{l}\text { Procenat izvrsenih preventivnih radova } \\
\text { održavanja (od predvidenih) na katego- } \\
\text { rijama sredstava NVO u kriznoj situa- } \\
\text { ciji }\end{array}$ & & \\
\hline & $\begin{array}{l}\text { Procenat izvršenih preventivnih radova } \\
\text { održavanja (od predviđenih) na katego- } \\
\text { rijama sredstava NVO u ratu }\end{array}$ & & \\
\hline & $\begin{array}{l}\text { Broj ljudi zaposlen u upravnim orga- } \\
\text { nima prema izvršnim u miru }\end{array}$ & $\begin{array}{l}\text { Po svakom nivou } \\
\text { posebno }\end{array}$ & \\
\hline & $\begin{array}{l}\text { Broj ljudi zaposlen u upravnim orga- } \\
\text { nima prema izvršnim u ratu } \\
\end{array}$ & $\begin{array}{l}\text { Po svakom nivou } \\
\text { posebno }\end{array}$ & \\
\hline & $\begin{array}{l}\text { Raspon opterećenja komandnih nivoa } \\
\text { po broju informacija koje se moraju } \\
\text { obraditi u ratu }\end{array}$ & $\begin{array}{l}\text { Svi komandni nivoi i } \\
\text { organi za održavanje }\end{array}$ & \\
\hline & $\begin{array}{l}\text { Raspon opterećenja komandnih nivoa } \\
\text { po broju informacija koje se moraju } \\
\text { obraditi u kriznim situacijama } \\
\end{array}$ & Isto & \\
\hline & $\begin{array}{l}\text { Raspon opterecenja komandnih nivoa } \\
\text { po broju informacija koje se moraju } \\
\text { obraditi u miru }\end{array}$ & Isto & \\
\hline \multirow{3}{*}{$\begin{array}{l}\text { ELAS- } \\
\text { TIĆNOST }\end{array}$} & $\begin{array}{l}\text { Operativna gotovost sredstava NVO } \\
\text { pri ekstremno visokim tehnoloskim za- } \\
\text { htevima (gubicima sredstava NVO) } \\
\end{array}$ & \multirow{3}{*}{$\begin{array}{l}\text { Po vrstama sred- } \\
\text { stava }\end{array}$} & \multirow{3}{*}{$\begin{array}{l}\text { Operativna gotovost izra- } \\
\text { Eunava se na istovetan } \\
\text { način kao i kod kriteri- } \\
\text { juma efektivnost. Kada } \\
\text { se misli na gubitke tehno- } \\
\text { loških elemenata podra- } \\
\text { zumevaju se linearni gu- } \\
\text { bici određenog procenta. }\end{array}$} \\
\hline & $\begin{array}{l}\text { Operativna gotovost sredstava NVO } \\
\text { pri gubitku tehnoloskih elemenata i } \\
\text { rezervi rezervnih delova do } 10 \%\end{array}$ & & \\
\hline & $\begin{array}{l}\text { Operativna gotovost sredstava NVO } \\
\text { pri gubitku tehnoloških elemenata i } \\
\text { rezervi rezervnih delova do } 20 \%\end{array}$ & & \\
\hline
\end{tabular}




\begin{tabular}{|c|c|c|c|}
\hline $\begin{array}{c}\text { Kriterijum } \\
0 . \text { nivoa }\end{array}$ & $\begin{array}{l}\text { Kriterijum } \\
\text { 1. nivoa }\end{array}$ & $\begin{array}{l}\text { Kriterijum } \\
\text { 2. nivoa }\end{array}$ & $\begin{array}{l}\text { Način određivanja } \\
\text { kriterijumskih vrednosti }\end{array}$ \\
\hline & $\begin{array}{l}\text { Operativna gotovost sredstava NVO } \\
\text { pn gubitku tehnoloskih elemenata i } \\
\text { rezervi rezervnih delova do } 30 \%\end{array}$ & & \\
\hline \multirow{5}{*}{$\begin{array}{l}\text { FLEKSI- } \\
\text { BILNOST }\end{array}$} & $\begin{array}{l}\text { Broj jedinica koje direktno stoje na } \\
\text { raspolaganju (kojima se direktno ko- } \\
\text { manduje) komandnim nivoima u miru }\end{array}$ & \multirow{5}{*}{$\begin{array}{l}\text { Po svakom nivou } \\
\text { posebno }\end{array}$} & \multirow{5}{*}{$\begin{array}{l}\text { Kriterijumske vrednosti } \\
\text { se dobijaju modelova- } \\
\text { njem }\end{array}$} \\
\hline & $\begin{array}{l}\text { Broj jedinica koje direktno stoje na } \\
\text { raspolaganju (kojima se direktno ko- } \\
\text { manduje) komandnim nivoima u ratu }\end{array}$ & & \\
\hline & $\begin{array}{l}\text { Procenat kapaciteta koji direktno stoje } \\
\text { na raspolaganju (kojima se direktno } \\
\text { komanduje) komandnim nivoima u } \\
\text { miru }\end{array}$ & & \\
\hline & $\begin{array}{l}\text { Procenat kapaciteta koji direktno stoje } \\
\text { na raspolaganju (kojima se direktno } \\
\text { komanduje) komandnim nivoima u } \\
\text { ratu }\end{array}$ & & \\
\hline & $\begin{array}{l}\text { Broj veza kojima se direktno ostvaruje } \\
\text { komandovanje održavanjem po ko- } \\
\text { mandnim nivoima }\end{array}$ & & \\
\hline \multirow{13}{*}{$\begin{array}{l}\text { TROŠ- } \\
\text { KOVI }\end{array}$} & Broj oficira & \multirow{13}{*}{ Nema } & \multirow{13}{*}{ Prebrojavanjem } \\
\hline & Broj podoficira & & \\
\hline & Broj civilnih lica profesionalaca & & \\
\hline & Broj vojnika mehaničara & & \\
\hline & Broj tenkova za izvlacenje & & \\
\hline & Broj vučnih vozova do $20 \mathrm{t}$ & & \\
\hline & Broj vučnih vozova do $50 \mathrm{t}$ & & \\
\hline & Broj auto-dizalica do $10 \mathrm{t}$ & & \\
\hline & Broj dizalica do $50 \mathrm{t}$ & & \\
\hline & Broj dizalica preko $50 \mathrm{t}$ & & \\
\hline & Broj pokretnih radionica & & \\
\hline & Broj vozila do 1,5 t za prevoz ekipa & & \\
\hline & $\begin{array}{l}\text { Broj stacionarnih punktova za održava- } \\
\text { nje u miru }\end{array}$ & & \\
\hline $\begin{array}{l}\text { JEDNO- } \\
\text { STAV- } \\
\text { NOST }\end{array}$ & $\begin{array}{l}\text { Prelazak sa mirnodopskog na ratno } \\
\text { stanje }\end{array}$ & $\begin{array}{l}\text { - odnos vojnog i po- } \\
\text { pisnog fonda vozila } \\
\text { - odnos mirnodop- } \\
\text { skog i ratnog sastava } \\
\text { - odnos broja goto- } \\
\text { vih jedinica i ukupnog } \\
\text { broja jedinica } \\
\text { - odnos broja jedi- } \\
\text { nica sa mirnodopskim } \\
\text { jezgrom i ukupnog } \\
\text { broja jedinica } \\
\text { - odnos broja jedi- } \\
\text { nica } \\
\text { - bez mirnodopskog } \\
\text { jezgra i ukupnog } \\
\text { broja jedinica }\end{array}$ & $\begin{array}{l}\text { Vrednosti kriterijuma iz- } \\
\text { računavaju se u vidu jed- } \\
\text { nostavnih odnosa }\end{array}$ \\
\hline
\end{tabular}




\begin{tabular}{|c|c|c|c|}
\hline $\begin{array}{c}\text { Kriterijum } \\
0 . \text { nivoa }\end{array}$ & $\begin{array}{l}\text { Kriterijum } \\
\text { 1. nivoa }\end{array}$ & $\begin{array}{l}\text { Kriterijum } \\
2 \text {, nivoa }\end{array}$ & $\begin{array}{c}\text { Nacin određivanja } \\
\text { kriterijumskih vrednosti }\end{array}$ \\
\hline \multirow{6}{*}{$\begin{array}{l}\text { JEDNO- } \\
\text { STAV- } \\
\text { NOST }\end{array}$} & $\begin{array}{l}\text { Prelazak na funkcionisanje u kriznim } \\
\text { situacijama }\end{array}$ & Nema & $\begin{array}{l}\text { Vrednost kriterijuma od- } \\
\text { reduje se ekspertskom } \\
\text { ocenom }\end{array}$ \\
\hline & $\begin{array}{l}\text { Broj mesta u liniji komandovanja gde } \\
\text { se obrađuju informacije, a taj nivo } \\
\text { nema izvršnih organa i ne realizuje } \\
\text { održavanje }\end{array}$ & Nema & \multirow{5}{*}{$\begin{array}{l}\text { Vrednosti kriterijuma iz. } \\
\text { računavaju se u vidu jed. } \\
\text { nostavnih odnosa. }\end{array}$} \\
\hline & $\begin{array}{l}\text { Procenat tehnoloških zahteva koje u } \\
\text { ratu može realizovati postojeci sistem } \\
\text { odrzavanja bez mobilizacije po katego- } \\
\text { rijama sredstava NVO }\end{array}$ & $\begin{array}{l}\text { Po vrstama sred- } \\
\text { stava }\end{array}$ & \\
\hline & $\begin{array}{l}\text { Procenat tehnoloskih zahteva koji se u } \\
\text { miru realizuju van vojnog sistema od- } \\
\text { ržavanja }\end{array}$ & Nema & \\
\hline & $\begin{array}{l}\text { Procenat tehnoloskih zahteva koji se u } \\
\text { ratu realizuju van vojnog sistema od- } \\
\text { ržavanja }\end{array}$ & Nema & \\
\hline & $\begin{array}{l}\text { Srednji procenat kapaciteta koji se pre- } \\
\text { liva sa višeg na niži nivo odrzavanja u } \\
\text { ratu }\end{array}$ & $\begin{array}{l}\text { Po svakom nivou } \\
\text { posebno }\end{array}$ & \\
\hline \multirow{3}{*}{$\begin{array}{l}\text { POKRE- } \\
\text { TLJI- } \\
\text { VOST }\end{array}$} & $\begin{array}{l}\text { Broj jedinica nivoa odeljenja za održa- } \\
\text { vanje koje mogu obavljati radove kori- } \\
\text { steci armijsku pokretnu remontnu } \\
\text { opremu }\end{array}$ & \multirow{3}{*}{$\begin{array}{l}\text { Po svakom nivou } \\
\text { posebno }\end{array}$} & \\
\hline & $\begin{array}{l}\text { Broj ekipa za održavanje koje se mogu } \\
\text { isturiti jednovremeno koristeći armij- } \\
\text { ska transportna sredstva }\end{array}$ & & \\
\hline & $\begin{array}{l}\text { Broj ekipa za održavanje koje se mogu } \\
\text { isturiti jednovremeno u ratu }\end{array}$ & & \\
\hline
\end{tabular}

\section{$\mathrm{K}_{3}^{0}$ - ELASTIČNOST}

Operativna gotovost izračunava se na istovetan način kao i kod kriterijuma efektivnost. Kada se misli na gubitke tehnoloških elemenata podrazumevaju se linearni gubici određenog procenta.

\section{$\mathrm{K}_{4}^{0}-$ FLEKSIBILNOST}

Kriterijumske vrednosti dobijaju se modelovanjem.

\section{$\mathrm{K}_{5}^{0}$ - JEDNOSTAVNOST}

Sve vrednosti potkriterijuma izračunavaju se u vidu jednostavnih odnosa. Drugi potkriterijum određuje se ekspertskom ocenom.

Neki od izabranih kriterijuma za ocenu sistema snabdevanja i transporta kao potceline LPSV, imaju određene karakteristike.

\section{$\mathrm{K}_{1}^{0}$ - EFEKTIVNOST}

Kriterijumske vrednosti za ovaj kriterijum izražavaju se verovatnoćom koja se dobija kao odnos vremena kada je korisnik obezbeđen dovoljnom količinom materijalnih sredstava i ukupnog vremena posmatranja. Kriterijum je opisan sa tri potkriterijuma, koji imaju svoje potkriterijume. Kriterijumske vrednosti dobijaju se modelovanjem. 
Kriterijumi za ocenu sistema snabdevanja i transporta

\begin{tabular}{|c|c|c|c|}
\hline $\begin{array}{l}\text { Kriterijum } \\
0 . \text { nivoa }\end{array}$ & $\begin{array}{l}\text { Kriterijum } \\
\text { 1. nivoa }\end{array}$ & $\begin{array}{l}\text { Kriterijum } \\
\text { 2. nivoa }\end{array}$ & $\begin{array}{l}\text { Način određivanja } \\
\text { kriterijumskih vrednosti }\end{array}$ \\
\hline \multirow{3}{*}{$\begin{array}{l}\text { EFEK- } \\
\text { TIVNOST }\end{array}$} & $\begin{array}{l}\text { Verovatnoća zadovoljenja potreba po } \\
\text { količini i vremenu u miru }\end{array}$ & \multirow{3}{*}{$\begin{array}{l}\text { Po vrstama sred- } \\
\text { stava }\end{array}$} & \multirow{3}{*}{$\begin{array}{l}\text { Kriterijumske vrednosti se } \\
\text { izražavaju verovatnoćm ko- } \\
\text { ja se dobija kao odnos vre- } \\
\text { mena kad je korisnik obe- } \\
\text { zbeđen dovoljnom količinom } \\
\text { materijalnih sredstava i } \\
\text { ukupnog vremena posmatra- } \\
\text { nja. Kriterijumske vrednosti } \\
\text { se dobijaju modelovanjem. }\end{array}$} \\
\hline & $\begin{array}{l}\text { Verovatnoća zadovoljenja potreba po } \\
\text { količni i vremenu u kriznim situaci- } \\
\text { jama }\end{array}$ & & \\
\hline & $\begin{array}{l}\text { Verovatnoća zadovoljenja potreba po } \\
\text { količini i vremenu u ratu }\end{array}$ & & \\
\hline \multirow{5}{*}{$\begin{array}{l}\text { EFIKAS- } \\
\text { NOST }\end{array}$} & Vreme realizacije zahteva & $\begin{array}{l}\text { Po vrstama sred- } \\
\text { stava }\end{array}$ & \multirow{5}{*}{$\begin{array}{l}\text { Sve kriterijumske vrednosti } \\
\text { se dobijaju modelovanjem. }\end{array}$} \\
\hline & Iskoriscenje tehnoloskih elemenata & $\begin{array}{l}\text { Po tehnoloskim } \\
\text { elementima }\end{array}$ & \\
\hline & $\begin{array}{l}\text { Broj pretovarnih mesta u liniji snabde- } \\
\text { vanja }\end{array}$ & $\begin{array}{l}\text { Po vrstama sred- } \\
\text { stava }\end{array}$ & \\
\hline & $\begin{array}{l}\text { Raspon opterećenja snabdevackih pun- } \\
\text { ktova u liniji snabdevanja }\end{array}$ & $\begin{array}{l}\text { Po vrstama sred- } \\
\text { stava }\end{array}$ & \\
\hline & $\begin{array}{l}\text { Raspon opterećenja komandnih nivoa } \\
\text { po broju informacija koje se moraju } \\
\text { obraditi }\end{array}$ & Nema & \\
\hline \multirow{4}{*}{$\begin{array}{l}\text { ELAS- } \\
\text { TIĆNOST }\end{array}$} & $\begin{array}{l}\text { Verovatnoća zadovoljenja potreba po } \\
\text { kolićini i vremenu pri ekstremno veli- } \\
\text { kim zahtevima }\end{array}$ & \multirow{4}{*}{$\begin{array}{l}\text { Po vrstama sred- } \\
\text { stava }\end{array}$} & \multirow{4}{*}{$\begin{array}{l}\text { Ovaj kriterijum se opisuje sa } \\
\text { cetiri potkriterijuma, koji ta- } \\
\text { kođe imaju svoje potkriteri- } \\
\text { jume. Kriterijumske vredno- } \\
\text { sti za ovaj kriterijum se izra- } \\
\text { žavaju na isti način kao i kod } \\
\text { kriterijuma efektivnosti, a } \\
\text { dobijaju se modelovanjem. }\end{array}$} \\
\hline & $\begin{array}{l}\text { Verovatnoća zadovoljenja potreba po } \\
\text { kolicini i vremenu pri gubitku tehno- } \\
\text { loških elemenata i materijalnih re- } \\
\text { zervi } 10 \%\end{array}$ & & \\
\hline & $\begin{array}{l}\text { Verovatnoća zadovoljenja potreba po } \\
\text { kolicini i vremenu pri gubitku tehnolo- } \\
\text { Skih elemenata i materijalnih rezervi } \\
20 \% \\
\end{array}$ & & \\
\hline & $\begin{array}{l}\text { Verovatnoca zadovoljenja potreba po } \\
\text { kolicini i vremenu pri gubitku tehnolo- } \\
\text { skih elemenata i materijalnih rezervi } \\
30 \%\end{array}$ & & \\
\hline \multirow{3}{*}{$\begin{array}{l}\text { FLEKSI- } \\
\text { BILNOST }\end{array}$} & $\begin{array}{l}\text { Sposobnost uspostavljanja organizacije } \\
\text { u konkretnoj situaciji u okviru predvi- } \\
\text { đenog načina funkcionisanja }\end{array}$ & \multirow{3}{*}{ Nema } & \multirow{3}{*}{$\begin{array}{l}\text { Ovaj kriterijum je opisan sa } \\
\text { tri potkriterijuma, a kriteri- } \\
\text { jumske vrednosti se dobijaju } \\
\text { ekspertskom ocenom. }\end{array}$} \\
\hline & $\begin{array}{l}\text { Sposobnost uspostavljanja organizacije } \\
\text { u kriznim situacijama }\end{array}$ & & \\
\hline & \begin{tabular}{|l|} 
Sposobnost uspostavljanja organizacije \\
u nepredviđenim situacijama u ratu \\
\end{tabular} & & \\
\hline \multirow{4}{*}{$\begin{array}{l}\text { TRO- } \\
\text { SKOVI }\end{array}$} & Broj transportnih sredstava & $\begin{array}{l}\text { Po vrstama sred- } \\
\text { stava }\end{array}$ & \multirow{4}{*}{$\begin{array}{l}\text { Kriterijumske vrednosti za } \\
\text { sve potkriterijume su brojevi } \\
\text { u apsolutnom iznosu. } \\
\text { Kriterijumske vrednosti se } \\
\text { određuju modelovanjem. }\end{array}$} \\
\hline & Broj manipulativnih sredstava & $\begin{array}{l}\text { Po vrstama sred- } \\
\text { stava }\end{array}$ & \\
\hline & Broj ljudi & $\begin{array}{l}\text { Po specijalno- } \\
\text { stima }\end{array}$ & \\
\hline & $\begin{array}{l}\text { Količina ešeloniranih materijalnih re- } \\
\text { zervi na operativnom i taktickkom nivou }\end{array}$ & $\begin{array}{l}\text { Po vrstama sred- } \\
\text { stava }\end{array}$ & \\
\hline
\end{tabular}




\begin{tabular}{|c|c|c|c|}
\hline $\begin{array}{c}\text { Kriterijum } \\
0 . \text { nivoa }\end{array}$ & $\begin{array}{l}\text { Kriterijum } \\
1 . \text { nivoa }\end{array}$ & $\begin{array}{l}\text { Kriterijum } \\
\text { 2. nivoa }\end{array}$ & $\begin{array}{c}\text { Način određivanja } \\
\text { kriterijumskih vrednosti }\end{array}$ \\
\hline \multirow{7}{*}{$\begin{array}{l}\text { JEDNO- } \\
\text { STAV- } \\
\text { NOST }\end{array}$} & $\begin{array}{l}\text { Prelazak sa mirnodopskog na ratno } \\
\text { stanje }\end{array}$ & $\begin{array}{l}\text { - odnos vojnog i po- } \\
\text { pisnog fonda } \\
\text { - odnos mimodop- } \\
\text { skog i ratnog sastava } \\
\text { - odnos broja goto- } \\
\text { vih jedinica i ukup- } \\
\text { nog broja jedinica } \\
\text { - odnos broja jedi- } \\
\text { nica sa mirnodop- } \\
\text { skog jezgra i ukup- } \\
\text { nog broja jedinica } \\
\text { - odnos broja jedi- } \\
\text { nica bez mirnodop- } \\
\text { skog jezgra i ukup- } \\
\text { nog broja jedinica }\end{array}$ & \multirow{7}{*}{$\begin{array}{l}\text { Za potkriterijume prelazak } \\
\text { sa mirnodopskog na ratno } \\
\text { stanje i odnos pokretnih } \\
\text { nepokretnih rezervi preko } \\
\text { svojih potkriterijuma kriteri- } \\
\text { jumske vrednosti su koefici- } \\
\text { jenti. Kriterijumske vredno- } \\
\text { sti za ove potkriterijume do- } \\
\text { bijaju se modelovanjem. } \\
\text { Kriterijumske vrednosti za } \\
\text { potkriterijume broj snabe- } \\
\text { vackih punktova u linij } \\
\text { snabdevanja u ratu, broj } \\
\text { objedinjenih snabdevackih } \\
\text { punktova u liniji snabdeva- } \\
\text { nja u ratu, broj mesta u liniji } \\
\text { komandovanja gde se obra- } \\
\text { đuju informacije, a taj nivo } \\
\text { nema izvršnih organa i ne } \\
\text { realizuje snabdevanje i broj } \\
\text { nezavisnih mesta gde se } \\
\text { prate materijalne rezerve su } \\
\text { brojevi koji izrażavaju kolici- } \\
\text { nu. Vrednosti ovih potkrite- } \\
\text { rijuma dobijaju se modelova- } \\
\text { njem. } \\
\text { Kriterijumske vrednosti za } \\
\text { potkriterijum prelazak na } \\
\text { funkcionisanje u kriznim si- } \\
\text { tuacijama dobijaju se eks- } \\
\text { pertskom ocenom. }\end{array}$} \\
\hline & $\begin{array}{l}\begin{array}{l}\text { Prelazak na funkcionisanje u kriznim } \\
\text { situacijama }\end{array} \\
\end{array}$ & Nema & \\
\hline & \multirow{2}{*}{\begin{tabular}{|l|}
$\begin{array}{l}\text { Broj snabdevačkih punktova u liniji } \\
\text { snabdevanja u ratu }\end{array}$ \\
$\begin{array}{l}\text { Broj objedinjenih snabdevačkih pun- } \\
\text { ktova u liniji snabdevanja u ratu }\end{array}$ \\
\end{tabular}} & $\begin{array}{l}\text { Po vrstama sred- } \\
\text { stava }\end{array}$ & \\
\hline & & Nema & \\
\hline & Odnos pokretnih i nepokretnih rezervi & $\begin{array}{l}\text { Po vrstama sred- } \\
\text { stava }\end{array}$ & \\
\hline & $\begin{array}{l}\text { Broj mesta u liniji komandovanja gde } \\
\text { se obrađuju informacije, a taj nivo } \\
\text { nema izvrsnih organa i ne realizuje } \\
\text { snabdevanje }\end{array}$ & Nema & \\
\hline & $\begin{array}{l}\text { Broj nezavisnih mesta gde se prate } \\
\text { materijalne rezerve }\end{array}$ & Po svakom nivou & \\
\hline \multirow{3}{*}{$\begin{array}{l}\text { POKRE- } \\
\text { TLJIVOST }\end{array}$} & Odnos pokretnih i ukupnih rezervi & \multirow{3}{*}{ Po svakom nivou } & \\
\hline & $\begin{array}{l}\text { Procenat materijalnih rezervi koje se } \\
\text { mogu pokrenuti transportnim kapacite- } \\
\text { tima na dan }\end{array}$ & & \\
\hline & $\begin{array}{l}\text { Procenat slobodnih transportnih kapa- } \\
\text { citeta }\end{array}$ & & \\
\hline
\end{tabular}

$\mathrm{K}_{2}^{0}$ - EFIKASNOST

Kriterijum je opisan sa pet potkriterijuma.

Kriterijumske vrednosti za potkriterijum vreme realizacije zahteva je vreme u apsolutnom iznosu od nastanka zahteva do zadovoljenja zahteva, dok se kriterijumske vrednosti za potkriterijum iskorišcenje tehnoloških elemenata izražavaju koeficijentom iskorišcenja. Za potkriterijum broj pretovarnih mesta u liniji snabdeva- nja kriterijumska vrednost je broj u apsolutnom iznosu. Kriterijumske vrednosti za potkriterijum raspon opterecenja snabdevačkih punktova $u$ liniji snabdevanja razlika su opterećenja između punkta sa najvećim i najmanjim opterećenjem. Opterećenje snabdevačkog punkta izražava se u količini materijala za manipulaciju po čoveku na dan. Za potkriterijum raspon opterećenja komandnih nivoa po broju informacija koje se moraju obraditi, razlika su opterećenja između nivoa sa 
najvećim i najmanjim opterećenjem, gde se opterećenje izražava u broju informacija po coveku na sat.

Sve kriterijumske vrednosti dobijaju se modelovanjem.

\section{$\mathrm{K}_{3}^{0}-$ ELASTIČNOST}

Ovaj kriterijum opisuje se sa cetiri potkriterijuma, koji takode imaju svoje potkriterijume. Kriterijumske vrednosti za ovaj kriterijum izražavaju se na isti način kao i kod kriterijuma efektivnosti, a dobijaju se modelovanjem.

\section{$\mathrm{K}_{4}^{0}-$ FLEKSIBILNOST}

Ovaj kriterijum opisan je sa tri potkriterijuma, a kriterijumske vrednosti se dobijaju ekspertskom ocenom.

\section{$\mathbf{K}_{5}^{0}-$ TROŠKOVI}

Ovaj kriterijum je opisan sa Cetiri potkriterijuma koji imaju svoje potkriterijume. Kriterijumske vrednosti za sve potkriterijume su brojevi u apsolutnom iznosu, osim za potkriterijum količina ešeloniranih materijalnih sredstava na operativnom i taktičkom nivou kod kojeg se kriterijumske vrednosti izražavaju u operativno-proračunskim jedinicama. Kriterijumske vrednosti određuju se modelovanjem.

\section{$\mathrm{K}_{6}^{0}$ - JEDNOSTAVNOST}

Ovaj kriterijum opisan je sa sedam potkriterijuma, od kojih neki takođe imaju svoje potkriterijume, kroz koje su izražene kriterijumske vrednosti kriterijuma.
Za potkriterijume prelazak sa mirnodopskog na ratno stanje i odnos pokretnih $i$ nepokretnih rezervi preko svojih potkriterijuma, kriterijumske vrednosti su koeficijenti. Kriterijumske vrednosti za ove potkriterijume dobijaju se modelovanjem. Kriterijumske vrednosti za potkriterijume broj snabdevackkih punktova $u$ liniji snabdevanja u ratu, broj objedinjenih snabdevačkih punktova u liniji snabdevanja u ratu, broj mesta u liniji komandovanja gde se obrađuju informacije, a taj nivo nema izvršnih organa i ne realizuje snabdevanje i broj nezavisnih mesta gde se prate materijalne rezerve jesu brojevi koji izražavaju količinu. Vrednosti ovih potkriterijuma dobijaju se modelovanjem. Kriterijumske vrednosti za potkriterijum prelazak na funkcionisanje $u \mathrm{kri}$ znim situacijama dobijaju se ekspertskom ocenom.

\section{Zaključak}

Pri ocenjivanju OTS-a kriterijumi nužno moraju da postoje, ali njihova formalizacija u svakom modelu ocenjivanja nije nužna. Formalizacija kriterijuma zavisi od primenjenog modela ocenjivanja, odnosno, u nekim modelima ocenjivanja izbor i određivanje relativne važnosti moguće je prepustiti ocenjivačima.

Izdvajanje, definisanje, formalizacija i struktuiranje kriterijuma zavisi od problema, predmeta i cilja ocenjivanja, izbora modela ocenjivanja, primenjene metode za ocenu i rangiranje, a prvenstveno od samog OTS-a.

U ovom radu su izdvajanje, formalizacija i struktuiranje kriterijuma za ocenu i rangiranje organizacije LPSV prikazani 
sa ciljem da se ukaže na to šta pri ocenjivanju treba uzeti u razmatranje, a ne da se daju konačni kriterijumi. Tek konkretizacijom problema, predmeta i cilja ocenjivanja, izborom modela ocenjivanja metode za ocenu i rangiranje za konkretni OTS moguce je izdvojiti i struktuirati kriterijume za ocenu i rangiranje varijanti organizacije logistickih pozadinskih sistema.
Literatura:

[1] Anders, A. A. i dr,; Projektirovanije zavodov, Mašinostrojenije, Moskva, 1982.

[2] Brdarevic, S.: Uspelnost održavanja, OMO, Beograd, 1988.

[3] Vujanovic, N.: Postavljanje sistema kvaliteta prema zahtevima serije standarda JUS ISO 9000, FIRASO, Beograd, 1994.

[4] Belisev, S. D.; Gurvic, F. G.: Matematicko-statisticeskic metodi ekspertnih ocenok, Statistika, Moskva, 1980.

[5] JUS 9000 - Standardi za upravljanje kvalitetom i obezbeđenje kvaliteta, SL SFRJ, br. $36 / 91$.

[6] Komparativna analiza $\mathrm{PoOb}$ VJ i logisticke podrłke stranih OS - studija, GS VJ, Beograd, 1998. 